\title{
Role of seasonality in the socio-economic development of rural areas of the southern part of the Republic of Karelia
}

\begin{abstract}
The objective of this work is to analyze the impact of seasonality on the socio-economic development of rural areas of the southern part of Karelia. This study is based on the field data obtained via semi-structured indepth interviews with experts from the local community. The results show that the influence of seasonality is rather indirect, being a constituent of other factors: economic, infrastructural, institutional, social, etc. Although seasonality is most often perceived as a negative phenomenon regarding socio-economic development, modern types of economic activity characterized by a peak of activity in different seasons of the year mitigate the effect of seasonality and even benefit from being seasonal. Based on the materials collected, a typology of rural settlements of the southern part of Karelia based on the nature of the effect of seasonality has been developed (with a predominantly positive and predominantly negative effect).
\end{abstract}

Keywords

Rural development $\bullet$ seasonality $•$ Northern Russia $・$ Republic of Karelia

(C) University of Warsaw - Faculty of Geography and Regional Studies
Alexey Naumov $\mathbb{C}$, Varvara Akimova $\mathbb{C}$, Daria Elmanova $\mathbb{C}$, Elizaveta Velichko $\mathbb{C}$, Mikhail Topnikov $\mathbb{C}$, Maxim Volkov $\mathbb{C}$, Alina Khusainova $\mathbb{C}$, Petr Shmyd $\mathbb{C}$,

Aleksandra Poturaeva $\mathbb{C}$, Elena Nosova $\mathbb{C}$

Department of Socio-Economic Geography of Foreign

Countries, Faculty of Geography, Lomonosov Moscow

State University, Moscow, Russia

e-mail: asnaumov@geogr.msu.ru

e-mail: varvaraakimova1576@gmail.com

e-mail: elmanova@gmail.com

e-mail: elizvelich@gmail.com

e-mail:mtopnikov@geogr.msu.ru

e-mail: volkov-m-s@mail.ru

e-mail: khusainova.lina@yandex.ru

e-mail.ru: shmydpetr6120321@mail.ru

e-mail:av-poturaeva@yandex.ru

e-mail: ktyf.199921@mail.ru

Received: 21 September 2019

Accepted: 24 March 2020
Introduction

With the growth of intraregional imbalances in the quality of life and welfare, and, as a result, the increase in the number of the rural residents moving to cities, one of the primary tasks that many countries, and the Russian Federation in particular, have to consider is fostering sustainable socio-economic development of rural areas. One of the problems facing rural areas is the high role of seasonality, which has significant economic and social consequences that have to be taken into account within the framework of an effective regional policy. The Republic of Karelia, situated in the North-West of European Russia, is prone to the effects of seasonality. This effect is augmented due to the fact that 13 out of 18 subdivisions of its sparsely populated 180.5 thousand square kilometers are equated to the regions of the Far North (a group of administrative regions of Russia located mainly north of the Arctic Circle comprising about one-third of Russia's total area, where special salary ratios are in place as well as social benefits for the residents). The other five are directly assigned to this category. Another two important features are the proximity of the agglomeration of St. Petersburg of six million, and a border of $798 \mathrm{~km}$ with Finland.

The aim of this research is to analyze the impact of seasonality on the socio-economic development of rural areas at the microgeographic level (level of rural settlements). This article strives to determine whether seasonality is an important factor of socio-economic development for Karelia; how seasonality influences socio-economic development, and the types of rural settlements depending on the level and kind of influence seasonality has on their socio-economic development. Our approach presents a complex analysis of every manifestation of seasonality affecting socio-economic development, whereas other studies tend to look at only one problem at a time (mobility only, summer residents only, etc.).

Theoretical approaches to seasonality in the life of rural settlements

The main difference between seasonal fluctuations of economic indicators and other cyclical economic fluctuations lies in their short duration and annual repetition. C. Basu directly describes the main feature of seasonal fluctuations as its "shortterm" nature (Basu, n.d.).

Main studies on seasonality consider it primarily a kind of hindrance to determining long-term economic cycles. One of the main statistical tasks, which is usually performed by econometric analysis, - the decomposition of time series - aims to adjust the seasonality of various phenomena to identify long-term trends. The development of methods and tools for assessing the role of seasonality in economic activity was carried out by economists E. Dagum (Dagum 1978), M. Lovell (Lovell 1963), S. Hylleberg (Hylleberg 1986) and others. Nevertheless, S. Hylleberg notes that the use of data cleared of the so-called "seasonal noise" in economic analysis can lead to the loss of important information about the functioning of various systems within a particular territory (Hylleberg 2008, p. 5788).

An important distinctive feature of seasonality is the connection between the causes of seasonal fluctuations and the seasons of the year. Factors that directly depend on the natural conditions that change during the year are the main reasons for seasonality in the economy of a particular settlement or an 
entire country. T. Baum and S. Lundtorp (Baum \& Lundtorp 2001) investigated seasonality within the tourism market, where they identified two types of seasonality:

- natural seasonality as a derivative of climatic conditions (air and water temperatures, precipitation levels and their types - solid or liquid, daylight duration, etc.),

- institutional seasonality, which is a consequence of a decision made by the masses of consumers.

According to the conclusions of T. Baum and S. Lundtorp, institutional seasonality is much less predictable than the natural one. Nevertheless, some stability is also inherent in [institutional seasonality]: the work of educational organizations with summer holidays significantly affects the quantity and quality of supply and demand in the field of tourism.

Institutional seasonality was examined in more detail by T. Jaditz (Jaditz 1994). He identified two main types of affecting factors:

- $\quad$ predictable and regular events (New Year and Christmas, etc.);

- social conditions affecting the choice of season for the implementation of certain plans (school holidays in summer, student holidays after the examination session).

Seasonality has a fairly long history of research among Soviet and Russian scientists. In his PhD thesis "Seasonal rhythms of socio-economic processes in the regions of Russia", D. Zemlyansky identifies the following main stages in which seasonality was studied in the XX century:

- establishing a scientific understanding of the intra-annual rhythm of socio-economic processes in the works of S. Kuznets(Kuznets 1933), P.Bursak (Bursak1931),A. M. Ginzburg and G. I. Dukor (eds Ginzburg \& Dukor 1930) in the 1920-1930s, when the focus was on seasonality in agricultural and industrial production;

- $\quad$ studying the growing role of behavioral and social factors in the seasonal fluctuations in the works of J. Miron (Miron 1996), R. Barsky (Barsky \& Miron 1988), G. Gill (Gill 1991), R. Rau (Rau 2007), and others in the late 1970s.

At the turn of the century, a number of Russian researchers continued to investigate seasonality, among them E. Yakovenko (Yakovenko, Bass \& Makhrov 1991), V. Gubanov (Gubanov 2002), B. Mazmanova (Mazmanova 2000), V. Tarasevich (Tarasevich 1991).

One of the main conclusions drawn by $D$. Zemlyansky is that seasonality is manifested precisely in accordance with socioeconomic processes (specifics in the operation of an enterprise, behavior of the labor force, etc.) and the rhythms of nature.

One of the modern scientific trends concerning seasonality is researching seasonal or temporal mobility in rural areas.

Until the 2000s, the topic of mobility in rural areas did not fall within the scope of prominent scientific research. But the appearance of John Urry's "new mobility" (Sheller \& Urry 2006) spurred interest in studying the elements of this in the life of rural settlements. All articles dedicated to "new mobility" in rural areas can be divided into two groups: 1) concentrating on the external (exogenous) influx of the population, and 2) studying the mobility of rural dwellers (endogenous). The first group prevails in sheer numbers and includes works regarding Australia and Canada, and partly Finland and Sweden. The main emphasis between them is slightly different. The Australian studies are focused on the palette of macro-factors that attract the population to a particular locality (all factors determining the environment favorable or unfavorable for population mobility). For example, the research regarding mobility in the settlements located along the Adelaide - Alice Springs - Darwin transport corridor revealed the different nature of migration in towns located near mineral deposits and centers located on the territory of local tribes (Carson \& Carson 2014). Great attention was also paid to the economic specialization of the settlement, which determines the system of macro-factors that make it more attractive. Problems connected with population mobility in sparsely populated and rural areas were also unearthed, including the "brain drain" (Taylor et al. 2016). The role of the "temporary population" in remote, sparsely populated communities was also analyzed based on the examples of Canada and Australia. It was noted that this influence is proportional to both the remoteness of the territory and the properties of the temporary population group. It is recommended for local communities to develop mechanisms for the most efficient use of such temporary groups and spend resources mainly on servicing their stay (Carson et al. 2016). Moreover, these works describe in detail the interactions of new arrivals (temporal consumers) and the local population (regular consumers of services) (Haslam McKenzie 2010). There is also the topic of the interaction with the local indigenous population and the uniformity of all social groups-"participants in mobility".

As far as Finnish or Swedish studies are concerned, they took a completely different path, namely defining main groups of visitors to the rural settlements: tourists, seasonal workers and those who own a house (a "second home"). The main issue investigated was their interaction with local communities. For tourists it is minimal, while for seasonal workers the interaction is much more visible, but they are rather interested only in earnings and are most likely to be put into a category of "losers" who were forced to go to work part-time in a rural settlement. It has been proven that homeowners have the greatest influence on local communities, but due to the lack of registration, they cannot fully integrate with them (Pitkänen et al. 2018). It was also noted that "second homes" are a widespread phenomenon in Finland. More often than not, a second home is constructed away from the settlements with a permanent population. Therefore, in settlements with a permanent population, the number of inhabitants decreases, and in "second home" communities it increases seasonally (Adamiak, Pitkänen \& Lehtonen 2016). Moreover, in Sweden it was found that people of retirement age who have a "second home" would choose between urban and rural housing in order to save income. Couples are likely to move to a rural settlement, whereas single people will most likely remain in the city. Elderly people whose plans included spending old age with nature also move to the countryside (Marjavaara \& Lundholm 2014).

The second group of articles (endogenous) is based on Urry's claim that mobility is a necessity. Therefore, the main area of research is a person's attachment to a place. Milbourne and Kitchen, for example, explore rural settlements in Wales. The authors, adherents of the theory of "new mobility", consider rural mobility a necessity, and a response of rural communities to the curtailing of the service sector. The inconvenience of mobility is partly compensated for by a person's attitude to their place of residence ("anchor"), with which the resident has social, cultural and linguistic connections. However, the authors warn that a further increase in mobility can lead to even greater negative consequences and even the loss of a person's connections with their rural settlement (self-identity) (Milbourne \& Kitchen 2014).

Methods of studying the impact of seasonality on the development of rural areas of the southern part of Karelia

The field studies were conducted on 26 January - 5 February 2019 in three municipal districts of the Republic of Karelia: Prionezhsky, Pryazhinsky and Olonetsky, where 22 rural settlements were visited (Vedlozero (948 inhabitants (2018)), Vidlitsa (1632), Derevyanka (1616), Ilinskiy (2810), Kvartsitny (808), Kindasovo (14), Kinerma (6), Kotkozero (744), Kroshnozero 
(319), Kuytezha (576), Ladva (2132), Matrosy (1389), Megrega (664), Mikhailovskoe (377), Nizhnyaya Salma (47), Novaya Vilga (1765), Rybreka (427), Svyatozero (658), Syapsya (338), Chalna (2580), Sheltozero (857), Essoila (1742) (Kareliastat 2019). Field work was also carried out in the centers of municipal districts: the urban village of Pryazha (3630 inhabitants), and the cities of Olonets (10 887) and Petrozavodsk (268 946) (Fig.1).

The choice of these areas was based on the similarity of their geographical location in the southern part of the Republic of Karelia near the Leningrad Region, the similarity of their economic structure, and the significant influence of the administrative center of the region - the city of Petrozavodsk. Moreover, the chosen case studies represent every type of economic activity and every type of rural settlement in Karelia.

The study was carried out with the help of semi-structured indepth interviews with experts from the local community. Despite the fact that this article is devoted to the study of seasonality, the collected material is much wider. We were interested not only and not so much in seasonality, but in how northern rural settlements live, remote from the largest cities and at the same time close to regional centers. In this regard, as part of the interview, we did not focus on seasonality. The conversation began with the general issues of life in the settlement. If the interviewees themselves began to talk about seasonality, then this topic was pursued. The idea was to pick up on what the respondent said. If this option did not succeed, then we asked if there was an annual cycle in production and rural life. Interviews were concluded with specific discussion about a list of seasonality options that we compiled when reviewing the literature and then expanded as the field studies progressed (when mentioned in other interviews).

We agreed on all interviews in advance. These were interviews with authorities (24 interviews), representatives of business (25), educational (45) and cultural institutions (18), as well as the general public (27). Therefore, we understand that we are looking at the influence of seasonality not from the viewpoint of ordinary people, but from the viewpoint of people who organize life. All interviews were recorded, and then the part that concerned seasonality was transcribed for this article. Each interview lasted from 1.5 to 2 hours. There were both individual and group interviews. For example, this was the case in schools, when different teachers were invited.

At the processing stage, key indicators of seasonality were identified. All in all, five main indicators were outlined: main source of income (mining, agriculture - large enterprises and small farms, forestry, tourism, temporal employment and other), private allotments, infrastructure, and summer residents.

The more detailed topics researched (within the four manifestations described above) were as follows:

- seasonality in the functioning of enterprises, the existence of high and low seasons in their work, part-time employment;

- temporary (informal) employment of the population during different seasons of the year and how this affects the incomes of local residents;

- $\quad$ role of private allotments in self-reliance of local residents;

- seasonal in - and out migrations to a rural settlement (summer residents of rural settlements, tourists, workers seasonally employed in the cities, etc.);

- a reflection of seasonality in the life of a rural settlement: for example, weather conditions and other seasonal factors affecting the functioning of engineering infrastructure, public transport, local trade, etc.;

\section{Results}

This section presents the main findings obtained through the interviews and is divided into subsections (agriculture, tourism, temporal employment, summer residents) according to

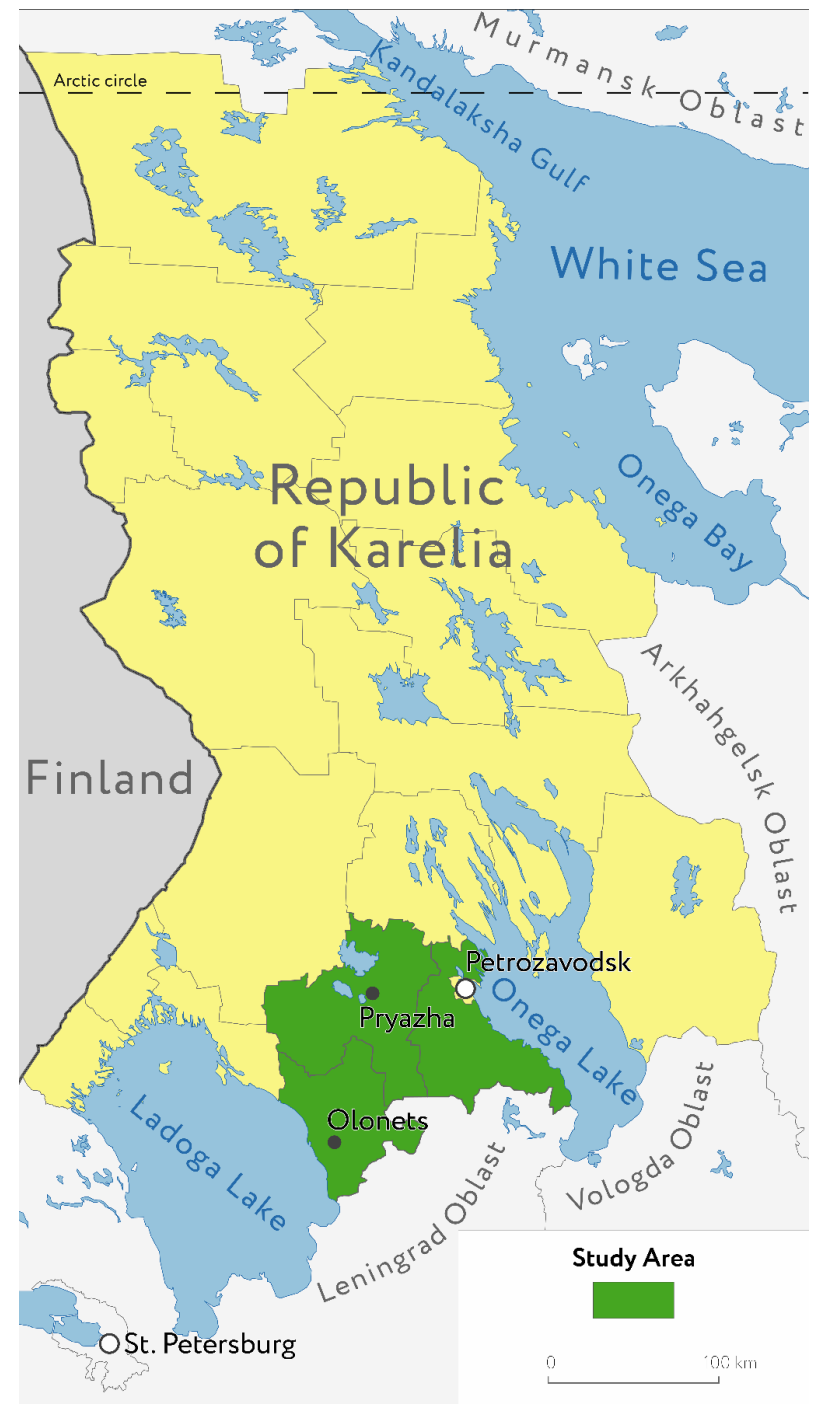

Figure 1. Study area. Source: OpenStreetMap 2019, Russia

the degree of importance attributed to different manifestations of seasonality by the interviewed experts starting from the most prominent. The findings conclude with the typology of rural settlements depending on the degree and nature of the influence of seasonality on socio-economic development, as described by local residents in the interviews.

The study revealed that the main factor determining the degree of influence of seasonality on rural residents is the economic function of the settlement, revealed through the employment of the local population. The following four types of settlements were identified, according to their functions:

- rural settlements with enterprises not associated with exploration of natural resources and therefore practically not affected by seasonality, except for issues related to the engineering infrastructure;

- rural settlements where mining is the main activity (i.e. stone, rubble, quartzite etc.), that are only slightly affected by seasonality, which affects how they function (e.g. transportation by waterways is ice-free only five months a year);

- rural settlements where most inhabitants are employed in agricultural or forestry enterprises, and seasonality affects 
MISCELLANEA GEOGRAPHICA - REGIONAL STUDIES ON DEVELOPMENT

Vol. 24 • No. 2 • 2020 • pp. 51-61 • ISSN: 2084-6118 • DOI: 10.2478/mgrsd-2020-0015

Table 1. Distribution and type of experts

\begin{tabular}{|c|c|c|c|c|c|}
\hline Settlement & $\begin{array}{l}\text { Staff of local } \\
\text { government }\end{array}$ & $\begin{array}{l}\text { Staff of educational and } \\
\text { health organizations }\end{array}$ & $\begin{array}{l}\text { Staff of cultural } \\
\text { organizations }\end{array}$ & Enterprise Staff & $\begin{array}{l}\text { Public figures, } \\
\text { members of public } \\
\text { and religious } \\
\text { organizations }\end{array}$ \\
\hline \multicolumn{6}{|c|}{ Prionezhsky District } \\
\hline Derevyanka & $\begin{array}{l}\text { 1. Head of rural } \\
\text { settlement }\end{array}$ & $\begin{array}{c}\text { 1. Senior kindergarten } \\
\text { teacher } \\
\text { 2. School Director }\end{array}$ & $\begin{array}{l}\text { 1. Librarian } \\
\text { 2. Director of house } \\
\text { of culture }\end{array}$ & & $\begin{array}{l}\text { 1. Retired ( } 2 \text { persons) } \\
\text { 2. Social activists } \\
\text { ( } 3 \text { persons) }\end{array}$ \\
\hline Ladva & $\begin{array}{l}\text { 1. Head of rural } \\
\text { settlement }\end{array}$ & $\begin{array}{l}\text { 1. School Director } \\
\text { 2. Deputy School Director } \\
\text { for pedagogical work } \\
\text { 3. Deputy School Director } \\
\text { for pre-school education } \\
\text { 4. Teacher of geography }\end{array}$ & & $\begin{array}{l}\text { 1. Director of farm } \\
\text { 2. Head of sales } \\
\text { department of } \\
\text { farm }\end{array}$ & $\begin{array}{l}\text { 1. Retired ( } 3 \text { persons) } \\
\text { 2. Social activists } \\
\text { ( } 3 \text { persons })\end{array}$ \\
\hline Kvartsitny & $\begin{array}{l}\text { 1. Head of rural } \\
\text { settlement }\end{array}$ & 1. School Director & $\begin{array}{l}\text { 1. Librarian } \\
\text { 2. Director of house } \\
\text { of culture }\end{array}$ & & $\begin{array}{l}\text { 1. Retired ( } 3 \text { persons) } \\
\text { 2. Social activists } \\
\text { ( } 2 \text { persons })\end{array}$ \\
\hline Sheltozero & $\begin{array}{l}\text { 1. Head of rural } \\
\text { settlement } \\
\text { 2. Deputy } \\
\text { member }\end{array}$ & $\begin{array}{l}\text { 1. School Director } \\
\text { 2. Deputy School Director } \\
\text { for pre-school education }\end{array}$ & $\begin{array}{l}\text { 1. Museum worker } \\
\text { 2. Director of } \\
\text { museum }\end{array}$ & & \\
\hline Rybreka & $\begin{array}{l}\text { 1. Head of rural } \\
\text { settlement }\end{array}$ & 1. School Director & $\begin{array}{l}\text { 1. Director of house } \\
\text { of culture }\end{array}$ & $\begin{array}{l}\text { 1. Director of } \\
\text { farm }\end{array}$ & \\
\hline Novaya Vilga & $\begin{array}{l}\text { 1. Head of rural } \\
\text { settlement }\end{array}$ & $\begin{array}{l}\text { 1. School Director } \\
\text { 2. Director of kindergarten }\end{array}$ & $\begin{array}{l}\text { 1. Director of house } \\
\text { of culture }\end{array}$ & & \\
\hline \multicolumn{6}{|c|}{ Olonetsky District } \\
\hline Kotkozero & $\begin{array}{l}\text { 1. Head of rural } \\
\text { settlement }\end{array}$ & $\begin{array}{l}\text { 1. Deputy School Director } \\
\text { for pedagogical work } \\
\text { 2. Teacher }\end{array}$ & 1. Librarian & $\begin{array}{c}\text { Forestry } \\
\text { employees } \\
\text { (3 persons) }\end{array}$ & $\begin{array}{l}\text { 1. Chairman of charity } \\
\text { organization } \\
\text { 2. Representative of } \\
\text { Veterans Council }\end{array}$ \\
\hline Olonets & $\begin{array}{l}\text { 1. Head } \\
\text { of district } \\
\text { administration } \\
\text { 2. Head of } \\
\text { Department of } \\
\text { public utilities } \\
\text { and transport }\end{array}$ & 1. Head physician & $\begin{array}{l}\text { 1. Director of } \\
\text { museum }\end{array}$ & $\begin{array}{l}\text { 1. Head of heating } \\
\text { network section } \\
\text { 2. General } \\
\text { Director of } \\
\text { transport } \\
\text { passenger } \\
\text { company }\end{array}$ & 1. Rector of Cathedral \\
\hline Ilinskiy & $\begin{array}{l}\text { 1. Head of rural } \\
\text { settlement }\end{array}$ & 1. School Director & & $\begin{array}{l}\text { 1. Director of farm } \\
\text { 2. Livestock } \\
\text { specialist } \\
\text { 3. Owner of tourist } \\
\text { complex }\end{array}$ & \\
\hline Vidlitsa & $\begin{array}{l}\text { 1. Head of rural } \\
\text { settlement }\end{array}$ & 2. School Director & 1. Librarian & $\begin{array}{l}\text { 1. Chief } \\
\text { agronomist of } \\
\text { farm } \\
\text { 2. Director of } \\
\text { residential home } \\
\text { for the elderly and } \\
\text { disabled } \\
\text { 3. Director of } \\
\text { tourist complex }\end{array}$ & \\
\hline
\end{tabular}


Continued Table 1. Distribution and type of experts

\begin{tabular}{|c|c|c|c|c|c|}
\hline Settlement & $\begin{array}{l}\text { Staff of local } \\
\text { government }\end{array}$ & $\begin{array}{l}\text { Staff of educational and } \\
\text { health organizations }\end{array}$ & $\begin{array}{l}\text { Staff of cultural } \\
\text { organizations }\end{array}$ & Enterprise Staff & $\begin{array}{l}\text { Public figures, } \\
\text { members of public } \\
\text { and religious } \\
\text { organizations }\end{array}$ \\
\hline \multicolumn{6}{|c|}{ Olonetsky District } \\
\hline Megrega & $\begin{array}{l}\text { 1. Head of rural } \\
\text { settlement }\end{array}$ & 1. School Director & & $\begin{array}{l}\text { 1. Director of } \\
\text { farm }\end{array}$ & $\begin{array}{l}\text { 1. Representative of } \\
\text { Veterans Council } \\
\text { 2. Retired village chief } \\
\text { 3. Member of cultural } \\
\text { association }\end{array}$ \\
\hline Kuytezha & $\begin{array}{l}\text { 1. Head of rural } \\
\text { settlement }\end{array}$ & & 1. Librarian & $\begin{array}{l}\text { 1. Director of farm } \\
\text { 2. Director of } \\
\text { residential home } \\
\text { for the elderly } \\
\text { 3. Deputy director } \\
\text { of residential } \\
\text { home for the } \\
\text { elderly }\end{array}$ & \\
\hline Mikhailovskoe & $\begin{array}{l}\text { 1. Head of rural } \\
\text { settlement }\end{array}$ & $\begin{array}{l}\text { 1. School Director } \\
\text { 2. Teacher of technology }\end{array}$ & & $\begin{array}{l}\text { 1. Individual } \\
\text { entrepreneur } \\
\text { (farming) } \\
\text { 2. Individual } \\
\text { entrepreneur } \\
\text { (forestry) }\end{array}$ & $\begin{array}{l}\text { 1. Chairman of } \\
\text { ethno-cultural public } \\
\text { organization }\end{array}$ \\
\hline \multicolumn{6}{|c|}{ Pryazhinsky District } \\
\hline Svyatozero & $\begin{array}{l}\text { 1. Deputy } \\
\text { head of rural } \\
\text { settlement }\end{array}$ & $\begin{array}{l}\text { 1. School Director } \\
\text { 2. Teacher of technology } \\
\text { 3. Teacher of pottering }\end{array}$ & & & \\
\hline Pryazha & $\begin{array}{c}\text { 1. Head of } \\
\text { education } \\
\text { Department } \\
\text { of Pryazhinsky } \\
\text { district } \\
\text { administration }\end{array}$ & 1. School Director & $\begin{array}{l}\text { 1. Employee of } \\
\text { ethnocultural center }\end{array}$ & & \\
\hline Kroshnozero & $\begin{array}{l}\text { 1. Head of rural } \\
\text { settlement }\end{array}$ & 1. School Director & & $\begin{array}{l}\text { 1. Director of } \\
\text { fish breeding } \\
\text { enterprise }\end{array}$ & \\
\hline Vedlozero & $\begin{array}{l}\text { 1. Head of rural } \\
\text { settlement }\end{array}$ & $\begin{array}{l}\text { 1. School Director } \\
\text { 2. Primary school teacher }\end{array}$ & $\begin{array}{l}\text { 1. Employee of } \\
\text { ethnocultural center }\end{array}$ & & \\
\hline Kinerma & & & & & $\begin{array}{l}\text { 1. Head of public } \\
\text { Fund for cultural } \\
\text { heritage preservation }\end{array}$ \\
\hline $\begin{array}{l}\text { Nizhnyaya } \\
\text { Salma }\end{array}$ & & & & 1. Director of farm & \\
\hline Essoila & $\begin{array}{l}\text { 1. Deputy } \\
\text { head of rural } \\
\text { settlement } \\
\text { 2. Head of } \\
\text { Department } \\
\text { of temporary } \\
\text { residence }\end{array}$ & $\begin{array}{l}\text { 1. Director of kindergarten } \\
\text { 2. Nurse in kindergarten } \\
\text { 3. School Director }\end{array}$ & $\begin{array}{l}\text { The staff of ethno- } \\
\text { cultural center: } \\
\text { 1. Producer } \\
\text { 2. Genre specialist } \\
\text { 3. Director }\end{array}$ & & \\
\hline Syapsya & & & & $\begin{array}{l}\text { 1. Director of } \\
\text { farm, cheese } \\
\text { maker }\end{array}$ & \\
\hline
\end{tabular}


MISCELLANEA GEOGRAPHICA - REGIONAL STUDIES ON DEVELOPMENT

Vol. 24 • No. 2 - 2020 • pp. 51-61 • ISSN: 2084-6118 • DOI: 10.2478/mgrsd-2020-0015

Continued Table 1. Distribution and type of experts

\begin{tabular}{|c|c|c|c|c|c|}
\hline Settlement & $\begin{array}{l}\text { Staff of local } \\
\text { government }\end{array}$ & $\begin{array}{l}\text { Staff of educational and } \\
\text { health organizations }\end{array}$ & $\begin{array}{l}\text { Staff of cultural } \\
\text { organizations }\end{array}$ & Enterprise Staff & $\begin{array}{l}\text { Public figures, } \\
\text { members of public } \\
\text { and religious } \\
\text { organizations }\end{array}$ \\
\hline \multicolumn{6}{|c|}{ Pryazhinsky District } \\
\hline Matrosy & $\begin{array}{l}\text { 1. Deputy } \\
\text { head of rural } \\
\text { settlement }\end{array}$ & $\begin{array}{l}\text { 1. School Director } \\
\text { 2. Nurse }\end{array}$ & & & 1. Retired village chief \\
\hline Kindasovo & $\begin{array}{l}\text { 1. Deputy head } \\
\text { of Pryazhinsky } \\
\text { district } \\
\text { administration }\end{array}$ & & & & \\
\hline Chalna & $\begin{array}{l}\text { 1. Head of rural } \\
\text { settlement }\end{array}$ & 1. School Director & $\begin{array}{l}\text { 1. Director of } \\
\text { ethnocultural center }\end{array}$ & $\begin{array}{l}\text { 1. Tour guide of } \\
\text { tourist center }\end{array}$ & \\
\hline Petrozavodsk & & $\begin{array}{l}\text { 1. Head of center for } \\
\text { the preservation of the } \\
\text { Karelian language } \\
\text { 2. Employee of center for } \\
\text { the preservation of the } \\
\text { Karelian language } \\
\text { The faculty and staff } \\
\text { of Petrozavodsk State } \\
\text { University: } \\
\text { 3. Professor of history } \\
\text { 4. Head of laboratory of } \\
\text { sociological research } \\
\text { 5. Head of Department } \\
\text { of animal science, fish } \\
\text { farming, agronomy and } \\
\text { land management } \\
\text { 6. Head of scientific work } \\
\text { The staff of Karelian } \\
\text { research centre of RAS: } \\
\text { 7. Researcher in folklore } \\
\text { studies } \\
\text { 8. Director of Institute of } \\
\text { Economics } \\
\text { 9. Leading researcher of } \\
\text { Department of regional } \\
\text { economic policy } \\
\text { 10. Leading researcher of } \\
\text { Department of institutional } \\
\text { development of regions } \\
\text { 11. Researcher of } \\
\text { Department of regional } \\
\text { development modeling } \\
\text { and forecasting } \\
\text { 12. Senior researcher at } \\
\text { Institute of Economics }\end{array}$ & & $\begin{array}{l}\text { 1. Director of } \\
\text { publishing house }\end{array}$ & $\begin{array}{l}\text { 1. Public figure, } \\
\text { expert on the rights of } \\
\text { indigenous peoples } \\
\text { 2. Expert in the } \\
\text { field of sustainable } \\
\text { development of } \\
\text { territories by means } \\
\text { of culture, Director of } \\
\text { Association of ethno- } \\
\text { cultural centers and } \\
\text { heritage preservation } \\
\text { organizations }\end{array}$ \\
\hline $\begin{array}{l}\text { Total number } \\
\text { of experts }\end{array}$ & 24 & 45 & 18 & 25 & 27 \\
\hline
\end{tabular}


how they function. The manifestation of seasonality in agriculture in the southern part of Karelia directly depends on the specialization of the enterprise (dairy farming or crop production), as well as on the size of the enterprise (large agricultural enterprises or small farms). Seasonality in agriculture is quite prominent in the technological process (harvesting, etc.), which affects the employment of workers and determines the nature of their relationship with the employer (permanent or temporary)

- rural settlements most susceptible to the influence of seasonality with no main enterprise and where the population is either self-employed or works on a rotational basis in other localities.

Additionally, it is necessary to analyze the role of seasonality in agribusiness and tourism, as well as its effect on informal employment of the population and waves of "summer residents" in more detail, as they are most responsive to the effect of seasonality.

\section{Agriculture}

Due to geographical location and climatic features, dairy farming is more widespread in the Republic of Karelia than crop production. All large agricultural enterprises in the southern part of Karelia are involved in dairy farming. Nowadays, modern livestock breeds are milked all year round despite the climatic conditions. Undeniably, the natural life cycle of a cow implies the birth of a calf and, accordingly, the maximum milk production mainly in winter. Yet, modern enterprises employ upto-date technologies, making sure that insemination takes place year-round, which eliminates seasonality in milk production. Consequently, stability in the production process at the large enterprises is reflected in the stability in the employment of its workers. All six large agricultural organizations in the southern part of Karelia (with the overall number of cattle exceeding 8000 , which is more than $35 \%$ of the total number of cattle in the Republic of Karelia (22 657 in 2018)), have permanent contracts with their employees, and most of the staff are employed there year-round (Kareliastat 2019).

As far as large cattle-breeding enterprises are concerned, seasonality has a stronger impact on temporary employment. In summer, many agricultural organizations conclude temporary contracts with additional workers mainly for harvesting (rural settlements llinskiy, Vidlitsa, Essoila, Megrega, Vedlozero). The number of these seasonal workers, as a rule, does not exceed 30 people in each of these settlements, which is quite low considering their overall population. Seasonal work generally requires the assistance of people with certain professional skills (tractor drivers, combine operators, lorry drivers). Therefore, the enterprises usually do not employ local residents.

Vegetables are mainly grown in open ground in Karelia, and its climatic conditions limit the possibilities for farmers: the period of growing vegetables in open ground is much shorter in Karelia than in Central and Southern Russia. In addition, there is the problem of wholesale distribution, since chain supermarkets are supplied with food products at lower prices from other regions of Russia. Small farms in Karelia are more specialized in crop production than large organizations as they produce niche commodities such as vegetables and herbs.

One of the most promising and profitable economic activities for Karelia is fish farming, the production process of which depends greatly on the season. According to data released at the International Trout Forum in 2019 held in Karelia, nearly 90\% of trout in Russia were bred in Karelia (Belyanchikov 2019). However, fish farms generate a small number of jobs (up to 10 per farm on average). In some localities, it was pointed out that the majority of workers employed there are not local residents. Additionally, the technological process of trout farming involves more labor input in winter than in summer. Temporary contracts that are concluded with employees do not usually cover the summer period. That is why in summer, if necessary, some workers are hired for construction work.

\section{Tourism}

Tourism is characterized by strongly pronounced seasonality, which is connected with uneven tourist flow throughout the year. Tourist visits to rural settlements are observed primarily during summer and over the New Year holidays. Undeniably, weather conditions play a major role, for example the warm weather in summer contributes to an increase in the number of visitors to lakes.

In summer, settlements situated near lakes experience an influx of "non-organized" tourists, who camp near the lakes. In turn, this exacerbates the problem of solid waste removal from coastal areas and increases pressure on lakes, rivers and forests because of fishing and berry and mushroom picking.

Seasonality is inherent in the functioning of tourist companies developing mainly winter tourism, e. g. those exploiting the brand of Talvi Ukko, the Karelian Father Frost in the Pryazha region and others specialized in cross-country skiing, ice fishing and snowmobiling.

Seasonal distribution of festival activities is also pronounced. Most of the open street events occur in summer, e. g. day of the village, memory watch (special event dedicated to honoring those who gave their lives on the battlefield during the Second World War), ethnic festivals, etc. At the same time, due to people being occupied with their private allotments, there is a decrease in the number of events organized by "houses of culture", or community clubs (center of cultural and educational work, financially supported by local authorities). Festivities in the offseason are more likely to be episodic. Unsurprisingly, such festivities do not attract a large number of tourists, primarily due to unfavorable weather conditions. Winter festivals organized by "houses of culture" are held indoors and are aimed mainly at local residents and people from the surrounding villages, with rare exceptions, such as the city of Olonets.

\section{Temporary (informal) employment}

Seasonality has the most noticeable effect on temporary activities. The Republic of Karelia has a high potential for harvesting and processing wild berries, the biological reserves of which (taking into account the average yield) are estimated to be over 120 thousand $\mathrm{t}$.

In all the rural settlements studied, local residents do pick berries in summer for sale. The following types of economic behavior of local residents have been identified:

- earnings from selling wild berries are the only or the most significant source of income (noted in 14 rural settlements). This usually applies to unemployed and retired rural residents; - earnings from selling wild berries are important, but only as an additional income (mainly in Sheltozero \& Ladva);

wild berries are picked for personal use only.

Wild berries are sold at special points of sale. These points of sale are either official, e. g. belonging to the company "Jagody Karelii" (Berries of Karelia) or to individual entrepreneurs, or unofficial. Berries are also sold on the highway near the rural settlement or in the city.

Picking berries for sale is so important that during the socalled "berry season" (July-August) that people often decline other possibilities of earning money, which sometimes causes complaints from local employers. 
Apart from wild berries, the residents mentioned that they also pick mushrooms, willow herb, and pine and spruce cones either to sell later or for their own needs.

Fishing is also quite popular. However, residents do not catch much - mostly for their own needs or just to sell to their neighbors. This is largely due to the tightening of legislation regarding usage of fishing nets. The Vepsian villages: Rybreka, Sheltozero and Kvartsitny are an exception in some ways. The status of indigenous small populations of the peoples of the North gives the Vepsians the right to catch fish on special conditions. These include annual fishing quotas: salmon $-1.8 \mathrm{t}$, whitefish $-0.36 \mathrm{t}$, pike perch $-0.27 \mathrm{t}$, vendace $-3.6 \mathrm{t}$, smelt $-10 \mathrm{t}$ (Shlyakhov 2010). Some of the local residents hope to use this advantage to attract tourists.

In addition, there is another kind of seasonal income for dwellers of rural settlements in Karelia - harvesting strawberries in the farms of nearby Finland. In 17 settlements in the southern part of Karelia, however, respondents noted that seasonal jobs of this kind ceased being a common occurrence due to institutional and economic reasons.

\section{"The phenomenon of summer residents"}

In rural areas in former Soviet territory, the phenomenon of "summer residents" (dachniki, those who spend summer in dacha (a seasonal or year-round second home, often located in the exurbs)) is quite widespread. It is demonstrated by the visible increase in the population of rural settlements during summer. As a result of in-depth analysis of the data obtained in the course of the interviews with local residents, several types of summer residents were identified, differing in seasonal influence on the settlement itself:

location of "dacha":

- in a garden non-commercial partnership (widespread form of non-commercial voluntary organization, created with the aim of joint management of small plots in rural areas);

- directly in the village

\section{by frequency of visits to "dacha":}

- only in summer, houses are not intended to be inhabited during the cold season (no gas or any other source for calefaction, except a traditional oven):

- all year round on weekends and holidays;

\section{by obtaining "dacha" in a rural settlement:}

- the house was inherited; local residents did not usually consider such dwellers who return to their "family nest" as summer residents;

- purchased houses, no relatives in the village.

Predominantly, summer houses in a garden non-commercial partnership are located in rural settlements near Petrozavodsk: Derevyanka, Ladva, Kvartsitny, Chalna and Novaya Vilga. According to the respondents, among local residents, "dacha" owners have next to no links with rural localities, for example, they prefer to buy food in Pryazha rather than use the services of local small shops. However, some summer residents participate in rural summer festivities and autumn fairs.

In other rural settlements, summer residents have much closer contact with the local residents. Since summer residents mostly come to houses of their families, they have the opportunity to stay there during the cold season and visit their "dachas" more often during the year, thus establishing stronger relationships with the local community.

Significant population growth caused by the arrival of summer residents was mentioned by all respondents in all the studied settlements. The increase in population puts more pressure on the infrastructure, transport, etc. This can be observed, for example, in the increased turnover in local shops. In some settlements, this does not cause any problems: in Sheltozero the variety of food products on offer expands in summer. In Kotkozero, Matrosy and Kroshnozero, sellers react to the appearance of summer residents and deliver more kinds of food. In Megrega, a mobile shop starts coming to the settlement.

In other settlements, the same phenomenon might cause problems, for example buying basic necessities such as bread becomes quite difficult due to the high demand, or high prices.

Types of rural settlements depending on the degree and nature of the influence of seasonality on socio-economic development

To determine the types of settlements based on the effect of seasonality on their socio-economic development, a comparison between the degree of influence of seasonality on employment and the change in population was made. As far as the effect of seasonality on employment is concerned, rural settlements can be divided into three groups: (a) "seasonless" (not depending on the season), where the majority of the population are employed in organizations such as the Home for the Disabled and Elderly (Vidlitsa), psychiatric hospital (Matrosy) and year-round tourism (Kinerma); (b) mining, influenced by seasonality to some extent; and (c) forestry and agriculture, including those where there is one main enterprise, as well as diversified employment of the local population. The effect of seasonality is somewhat mitigated in the settlements located not far from Petrozavodsk: Novaya Vilga, Chalna and Derevyanka. This happens mostly due to everyday migrations: commuting (both from rural settlements to the city, and vice versa to work at the mining sites); relocation of urban citizens to rural settlements by buying private property but continuing to have their place of work in Petrozavodsk.

In terms of the effect that seasonality has on the population the following groups of settlements can be identified: those located mainly on the lakeshores, thus attractive to summer residents and tourists; those surrounded by garden noncommercial partnerships, but much less influenced by the influx of summer residents and tourists, located not far from Petrozavodsk; and small settlements, where summer residents are mainly those who move to the city and return to their old houses during summer. Kinerma, a prominent tourist center, is an exception, where seasonality has practically no effect due to the relatively stable year-round flow of tourists.

When comparing the degree of influence of seasonality on employment and on the tourist (and summer residents) flows all together, two main types of rural settlements have been identified; on which seasonality has a predominantly positive and predominantly negative effect (Fig.2).

The predominantly positive effect of seasonality is mainly reflected in the possibility of realizing tourism potential.

1a Medium-sized settlements (427-1814 inhabitants), the local population of which is employed mainly in the mining industry. A location near the lakes or existence of an amusement park attract summer residents and tourists to these settlements (Chalna, Essoila, Kvartsitny, Rybreka). This type also includes Sheltozero. Despite the fact that there are no mining facilities in the settlement itself, Sheltozero has commuting links with Rybreka and Kvartsitny. Moreover, there is a stone processing plant operating in the settlement. Sheltozero is also similar to Rybreka and Kvartsitny in terms of ethnic features: all three settlements have a Vepsian population. Localities of this type benefit from seasonality: they have great potential for the development of tourism, but at the same time, the main economic activity (in this case mining) of the local population brings a stable high income, which is not prone to large seasonal fluctuations. 


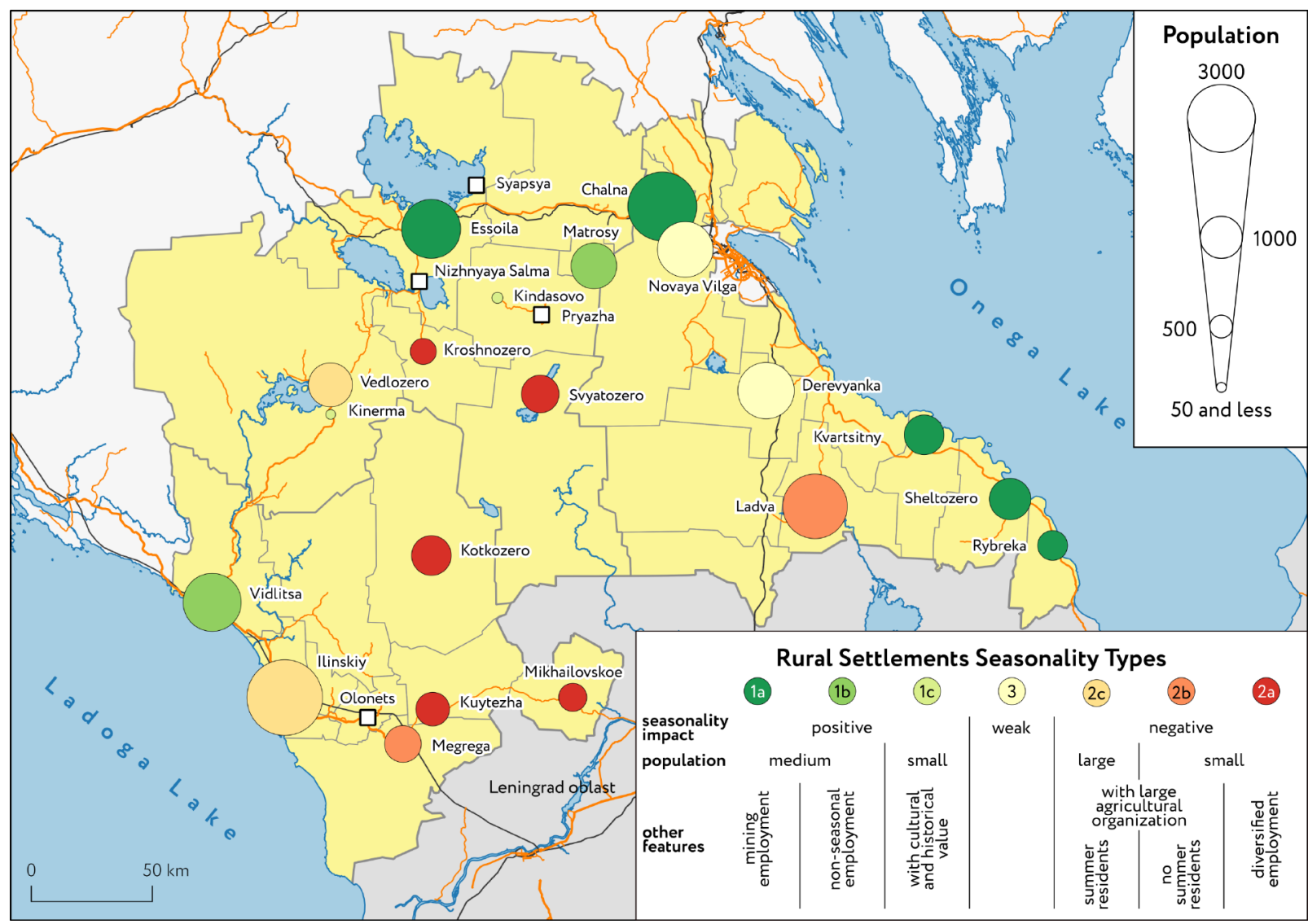

Figure 2. The southern part of the Republic of Karelia: types of rural settlements according to the influence of seasonality on socio-economic development (in the opinion of local residents). Source: data obtained from interviews, Kareliastat 2019, Municipal statistics

1b. Medium-sized settlements (1504-1632 inhabitants), the main population of which is employed at enterprises that do not depend on the season (the Home for the Disabled and Elderly (Vidlitsa), psychiatric hospital (Matrosy)). The main effect of seasonality here is large tourist flow. Like mining settlements, they have a great tourist potential, which can be considered a positive impact of seasonality.

1c. Very small settlements (6-14 inhabitants) without a "coreforming" enterprise but where there are places of cultural and historical value. Kinerma has already taken measures to realize its tourist potential and here seasonality practically does not affect tourist flow. Kindasovo attracts tourists mainly in summer for the annual festival of humor, but tourism is not the main economic activity, which means that the village is still vulnerable to the negative effect of seasonality. The main population of Kindasovo is people of retirement age, while the organizers of the festival live in other places and only come to the village for this event.

The predominantly negative effect of seasonality can be viewed in employment tendencies.

2a Small settlements (319-744 inhabitants) with diversified employment of the population, in which the majority of summer residents are former residents (Mikhailovskoye, Kuytezha, Kotkozero, Svyatozero, Kroshnozero). These settlements are most vulnerable to the negative impact of seasonality due to the lack of permanent stable income. All this contributes to migration of local residents to other settlements, the extinction of whole villages, and their transition to the category of special summer villages inhabited only during this time of year. 2b. Settlements with a large agricultural enterprise and a small number of summer residents (Ladva (2132 inhabitants), Megrega (664)). These settlements are very susceptible to seasonality in terms of employment due to the specific nature of the production process: more employees are needed in summer (for plant, harvest, etc.) than in winter.

2c. Rather largely populated settlements (948-2810 inhabitants) that have a large main enterprise specializing in agriculture and have a significant number of summer residents in (llinskiy (2810) and Vedlozero (948)). These settlements are susceptible to seasonality in terms of both employment (most likely the negative impact of seasonality will include mass departure of workers during the "berry season", which impedes the functioning of the enterprises) and flow of summer residents (which puts a strain on operation of local shops, the solid waste removal system, and even safety on the streets due to dogs being left to fend for themselves for the winter).

3. Novaya Vilga (1765 inhabitants) and Derevyanka (1616 inhabitants) fall into a separate category. They represent mediumsized mining settlements, surrounded by garden non-commercial partnerships and located quite close to Petrozavodsk. The effect of seasonality in these locations on employment (due to commuting) or population fluxes (due to summer residents or tourists) is minimal. These settlements have strong links with Petrozavodsk, which also significantly mitigate the impact of seasonality.

The nature of the influence of seasonality is reflected in the general mood of the local residents. In almost all the settlements 
that we assigned to the group with a predominantly positive effect of seasonality, we met active representatives of government, business and the public, who demonstrated a positive attitude and shared with us big plans for the future of their village. At the same time, in settlements that belonged to a different group (with a predominantly negative effect of seasonality) various complaints and memories of a better past were mentioned during the interviews.

\section{Discussion}

Having outlined the main options regarding how seasonality influences socio-economic development in rural settlements in the southern part of Karelia, we do believe that further research should be conducted. Our field studies were carried out during winter, therefore the first area in which further research is required is the summer period, when the seasonal population groups described (e.g. summer residents) can be interviewed. Secondly, by broadening the scope of interviewees to include the general public (as here views on the influence of seasonality were gathered from people who organize life (authorities, representatives of business, etc.)) we would be able to draw a more objective complex conclusion on the role of seasonality in the life of rural settlements.

We also hope that our findings might be useful for the local authorities when establishing the strategy of socio-economic development of their region not only in Karelia but in similar regions of the Far North of the Russian Federation (e.g. the Arkhangelsk region, Komi Republic etc.) as our case studies cover a wide range of economic activity and types of rural settlements.

\section{Conclusions}

Among the factors affecting the socio-economic development of rural areas in the southern part of Karelia, seasonality is of great importance. However, its influence is rather indirect, being one of the building blocks of other factors, such as economic, infrastructural, institutional, social factors, etc. Proximity to the regional center - Petrozavodsk - lessens the impact seasonality has on rural areas (this is observed in such settlements as Novaya Vilga, Derevyanka).

Seasonality is most often perceived as a negative phenomenon regarding the socio-economic development of rural areas (primarily due to changes in employment). Traditionally, seasonality implied a high level of intensity of economic activities in summer and a low level in winter. At present, modern types of economic activity are being developed in southern part of Karelia such as tourism and fish farming, which are characterized by a peak of activities at different times of the year. In this connection, the maximum level of economic activities in summer has levelled out somewhat (Chalna, Kotkozero). However, in some settlements, various types of economic activities have a similar annual cycle, which reinforces the effect of seasonality and exacerbates the corresponding problems of employment (Vedlozero, llinskiy).

The economic function of a settlement has a great influence on its resilience to the effects of seasonality. In particular, in southern part of Karelia, seasonality has a minimal impact on settlements where there are large enterprises that specialize in social welfare. Such organizations are least dependent on weather conditions and use of natural resources, thereby being "seasonless" (Matrosy, Vidlitsa).

Seasonality has a significant impact on crop production due to its dependence on agroclimatic conditions and the specific nature of the technological process. On the other hand, for dairy cattle breeding - mostly developed in southern Karelia (Megrega, llinskiy) - the change of seasons has practically no importance, partly due to new approaches to the production process (year-round insemination, etc.).

As in all of Russia, temporary (informal) employment such as picking and selling wild berries, mushrooms, herbs, etc. depends most on seasonality. Such commodities are sold directly to visiting tourists and / or summer residents, and representatives of processing companies.

The increase in population at the expense of summer residents and tourists in summer has a twofold effect. On the one hand, there is an increase in trade in local stores, in the demand for the services of the local libraries, and in the number of participants in rural cultural events (Sheltozero, Kotkozero, Matrosy, Kroshnozero, Megrega). On the other hand, in some settlements, this leads to higher prices and the inability to purchase essential goods due to high demand (Derevyanka, Mikhailovskoe, Essoila). In addition, the pressure put on the solid waste removal system also increases in summer.

There is a clear geographical pattern in the effect of seasonality on rural settlements in the southern part of Karelia: this increases from the east (mining areas) to the west (agricultural areas). While seasonality is more pronounced on the shores of lakes, proximity to Petrozavodsk, on the contrary, has a leveling effect and practically neutralizes the impact of seasonality.

Based on the materials collected during the expedition, a typology of rural settlements of the southern part of Karelia has been developed. This typology demonstrates the influence of seasonality on their socio-economic development from the point of view of local residents. Two main types of rural settlements have been identified (with a predominantly positive and predominantly negative effect of seasonality), as well as a special type on which the effect of seasonality is little.

We do hope that our findings will be useful for the local authorities when establishing the strategy of socio-economic development of their municipalities and settlements. For instance, such recommendations include establishing aquaculture enterprises in rural settlements with water bodies, as this industry functions all year round, fostering tourism not only during the assumed summer season. They also include adjusting the needs of the settlements to the inflow of summer residents, and trying to satisfy demand for food supply and basic services such as public transport, health care and entertainment.

\section{Acknowledgements}

The authors would like to express particular gratitude to V. V. Labinov - Deputy Prime Minister, Minister of Agriculture and Fishery of the Republic of Karelia, S. O. Terentyev Leading Specialist of the Department of Investments and Rural Development of the Ministry of Agriculture and Fishery of the Republic of Karelia, and to all local people for their help with organizing this field trip and invaluable insights concerning life in rural settlements in Karelia.

\section{ORCID}

Alexey Naumov (D) https://orcid.org/0000-0002-5099-212X

Varvara Akimova (1D https://orcid.org/0000-0003-0071-1307

Daria Elmanova (1) https://orcid.org/0000-0002-5630-1596

Elizaveta Velichko (D) https://orcid.org/0000-0003-3493-8227

Mikhail Topnikov (D) https://orcid.org/0000-0003-0658-9322

Maxim Volkov (1) https://orcid.org/0000-0002-3755-4934

Alina Khusainova (iD https://orcid.org/0000-0002-6175-1903

Petr Shmyd (10) https://orcid.org/0000-0001-7390-8819

Aleksandra Poturaeva (D) https://orcid.org/0000-0002-0256-2870

Elena Nosova (ID https://orcid.org/0000-0002-3268-0376 
Adamiak, C, Pitkänen, K \& Lehtonen, O 2016, 'Seasonal residence and counterurbanization: the role of second homes in population redistribution in Finland', GeoJournal, vol. 82(5), pp. 1035-1050.

Barsky, RB \& Miron, JA 1988, The seasonal cycle and the business cycle, National Bureau of Economic Research.

Basu, C n. d., The difference between seasonal economic fluctuations \& cyclical economic fluctuations. Available from: <http://smallbusiness.chron.com/difference-betweenseasonal-economic-fluctuations-cyclical-economicfluctuations-36101.html>. [5 March 2019].

Baum, T \& Lundtorp, S (eds) 2001, Seasonality in tourism, Elsevier.

Belyanchikov, E 2019, 'Three truths about the goldfish. As Karelians against the trout-breeders rebelled. Part 1. Journalistic investigation', Karelia News, 18 March. Available from: <https://www.karelia.news/news/2328785/tri-pravdypro-zolotuu-rybku-kak-karely-protiv-forelevodov-vosstalicast-1-zurnalistskoe-rassledovanie>. [20 March 2019].

Bursak, PJ 1931, Seasonal variations in employment in manufacturing industries, University of Pennsylvania, Philadelphia.

Carson, DB \& Carson, DA 2014, 'Local economies of mobility in sparsely populated areas: Cases from Australia's spine', Journal of Rural Studies, vol. 36, pp. 340-349.

Carson, DA, Cleary, J, Barre, S, Eimermann, M \& Marjavaara, R 2016, 'New mobilities - new economies? Temporary populations and local innovation capacity in sparsely populated areas', Settlements at the edge: Remote human settlements in developed nations, pp, 178-206.

Dagum, EB 1978, 'Modelling, forecasting and seasonally adjusting economic time series with the X-11 ARIMA method', Journal of the Royal Statistical Society. Series $D$ (The Statistician), vol. 27, no.3/4, pp. 203-216.

Gill, GJ 1991, Seasonality and agriculture in the developing world: A problem of the poor and powerless, Cambridge University Press, Cambridge.

Ginzburg, M \& Dukor, GI (eds) 1930, Seasonality and seasonal fluctuations in industry and the national economy, State Technical Publishing House, Moscow.

Gubanov, VA 2002, Non-parametric extraction of dynamic seasonal cycles: Working paper, State University - Higher School of Economics, Moscow.

Haslam McKenzie, F 2010, 'Fly-in fly-out: The challenges of transient populations in rural landscapes', Demographic Change in Australia's Rural Landscapes, vol. 12, pp. 353374.

Hylleberg, S 1986, Seasonality in regression, Academic Press, Orlando.

Hylleberg, S 2008, 'Seasonal adjustment' in The New Palgrave Dictionary of Economics, 2nd edition, eds SN Durlauf \& LE Blume, Palgrave Macmillan, London, pp. 5788-5797.

Jaditz, T 1994, 'Seasonality: economic data and model estimation', Monthly labor review, vol. 117, no. 12, pp. 1722.

Kareliastat 2019, Municipal statistics. Available from: <http:// $\mathrm{krl} . g \mathrm{ks} . \mathrm{ru} / \mathrm{wps} / \mathrm{wcm} / \mathrm{connect} /$ rosstat_ts/krl/ru/municipal_ statistics>. [20 March 2019].

Kuznets, S 1933, Seasonal variations in industry and trade, National Bureau Economic Research, New York.

Lovell, MC 1963, 'Seasonal adjustment of economic time series and multiple regression analysis', Journal of the American Statistical Association, vol. 58, no. 304, pp. 993-1010.
Marjavaara, R \& Lundholm, E 2014, 'Does second-home ownership trigger migration in later life?', Population, Space and Place, vol. 22(3), pp. 228-240.

Mazmanova, BG 2000, 'Methodical issues of sales forecasting', Marketing in Russia and abroad, no. 1, pp. 21-35.

Milbourne, P \& Kitchen, L 2014, 'Rural mobilities: Connecting movement and fixity in rural places', Journal of Rural Studies, vol. 34, pp. 326-336.

Miron, JA 1996, The economics of seasonal cycles, Massachusetts Institute of Technology, Massachusetts.

OpenStreetMap 2019, Russia. Available from: <http:// openstreetmap.ru>. [15 June 2019].

Pitkänen, K, Sireni, M, Rannikko, P, Tuulentie, S \& Hiltunen, MJ 2018, 'Temporary mobilities regenerating rural places. Case studies from northern and eastern Finland', Journal of Rural and Community Development, vol. 12 (2-3), pp. 93-113.

Rau, R 2007, Seasonality in human mortality: a demographic approach, Springer. Berlin, Heidelberg, Germany.

Shlyakhov, Y 2010, 'Fishing quotas have been allocated to the Vepsians', "Karelia Official" official Internet portal of the Republic of Karelia (gov. karelia.ru), 3 August. Available from: <http://www.gov.karelia.ru/gov/News/2010/08/0803_18. $\mathrm{html}>$. [11 March 2019].

Tarasevich, VM 1991, Economic-mathematical methods and models in pricing. Part 1, Publishing house of the Leningrad Financial and Economic Institute, Leningrad.

Taylor, A, Carson, DB, Ensign, PC, Huskey, L, \& Rasmussen, RO 2016, 'Settlements at the edge: Remote human settlements in developed nations', Edward Elgar Publishing.Gloucester, UK.

Sheller, M \& Urry, J 2006, 'The new mobilities paradigm', Environment and Planning A, vol. 38(2), pp. 207-226.

Yakovenko, EG, Bass, MI \& Makhrov, NV 1991, The life cycles of economic processes, objects and systems, Nauka, Moscow. 